\title{
Productivity of a cereal-row crop rotation in the context of an applied biologization practice
}

\author{
Natalya Chuyan*, Galina Breskina, Maya Priputneva, and Anastasiya Okuneva \\ FSBSI "Federal Agricultural Kursk Research Center" 70b, Karl Marx St., Kursk, 305021, Russia
}

\begin{abstract}
The research was carried out to study the effect of biological preparations (Gribofit and Imunazot), applied both separately and together with nitrogen fertilizers (at the rate of $10 \mathrm{~kg}$ of NPPN. per 1 ton of straw) with the use of by-products as fertilizer on crop yield and productivity of the link of the cereal-row crop rotation "sunflower-barley-soybean". The work was carried out in 2018-2020 in Kursk Region on typical slightly eroded heavy-loamy chernozem. The results are obtained for the following variants: 1. crushed by-products of crop rotation crops (control); 2. crushed by-products of crop rotation crops + nitrogen fertilizers at the rate of $10 \mathrm{~kg}$ of NPPN per 1 ton of cereal straw; 3 . crushed by-products of crop rotation crops + biological preparations (Gribofit and Imunazot); 4. crushed by-products of crop rotation crops + biological preparations (Gribofit and Imunazot) + nitrogen fertilizers at the rate of $10 \mathrm{~kg}$ of NPPN per 1 ton of cereal straw. The results of the studies showed that the application of biological preparations against the background of surface embedded crop by-products provided an increase in the yield of all the crops of the crop rotation link in relation to the control. But higher efficiency was noted when using nitrogen fertilizers against the background of the applied crushed plant residues, it was 10.67 thousand grain units per 1ha, which exceeded the control by 3.19 thousand grain units per 1 ha $(42.6 \%)$.

Keywords: crop yield, productivity, crop rotation, biopreparation, by-product, nitrogen fertilizers.
\end{abstract}

\section{Introduction}

The introduction of environmentally safe and economically sound crop cultivation technologies in modern agricultural production allows not only to increase the yield and quality of crop production [1], but also minimize anthropogenic impact. In this regard, there is an increased interest in the methods of biologization of agriculture and resource conservation using biological plant protection products, growth regulators, by-products of crops as organic fertilizers and microbiological preparations of a wide spectrum of action $[2,3]$.

The effectiveness of biopreparations is determined not only by an increase in the rate of decomposition of postharvest plant residues [4], which raises biological activity of the soil, but also contributes to the improvement of water, air and nutrient soil regimes, which are the main factors in the formation of a high-quality crop yield [5].

The use of biopreparations leads to an improvement in plant growth by reducing the stress effect on the plant of unfavorable environmental conditions, contributes to the most complete disclosure of the potential of the variety, which relates to both quantitative and qualitative indicators of agricultural products $[6,7]$, and proves the feasibility of treating straw with biopreparations before embedding it into the soil[8].

Along with certain positive results indicating the effectiveness of biopreparations used for straw inoculation $[9,10]$, experimental data from some researchers $[11,12]$ indicate the absence of a stable sustainable effect in improving soil quality and increasing crop yields.

According to American scientists [13], competition with the community of native microflora, as well as the buffering of the soil ecosystem in relation to the introduced modifiers, is the main limiting factor for obtaining a stable positive effect from their use [14].

In Central Chernozem Region (CChR), cereal crops occupy a leading position, but in the last five years, there has been an increase in the area of arable land under row crops. Thus, the area of sunflower in Kursk Region is more than 47 thousand hectares, which indicates the need to study new technologies for growing this crop with the involvement of microbiological preparations [15]. It was revealed that the treatment of sunflower seeds with biological preparations contributed to the improvement of the bioresource potential and sowing qualities of sunflower crop [16]

Much attention is paid to the study of the effect of biopreparations on the yield of spring barley [17], where on the average the studied indicator was higher than the control by $10 \%$.

Regulators of plant growth and development have the ability to positively influence the yield and quality of soybean seeds. Maximum efficiency is achieved by combining seed treatment and foliar dressing, with stepby-step stimulation of treated seeds and plants with biologically active substances of the preparations. For the successful cultivation of soybeans, it is necessary to observe agronomical practices, one of which is the inoculation of soybean seeds with rhizobic preparations; 
it is mandatory not only for the introduction of this crop in new territories, but even in those areas where soybean has already been cultivated, since the treatment of seeds with specially selected highly active strains of nodule bacteria significantly increases the yield of plants.

Biopreparations had a positive effect on the growth and development of soybean plants. When they were used, the weight of 1000 seeds significantly increased, compared with the control by $22.0 \%$. The highest yield was observed in the variant with the use of Bactofit and Mival-Agro, the increase to the control was 50\% [21].

Based on the above material, it is established that biopreparation supplied together with plant residues give an increase in crop productivity. However, their effect is significantly inferior to the variant with the nitrogen fertilizers applied with plant residues. Since the activity of biological preparations depends on the soil and climatic conditions, it is difficult to reveal their potential without an additional resource, including application of organic and mineral fertilizers [9]. In this regard, an experiment was laid out to study the joint effect of biopreparations (Gribofit and Imunazot) and nitrogen fertilizers (at a rate of $10 \mathrm{~kg}$. of NPPN per 1 ton of straw) with the surface embedding of crushed plant residues

The aim of the research is to study the effect of biological practices (application of crushed by-products with biopreparations Gribofit and Imunazot or with nitrogen fertilizers at the rate of $10 \mathrm{~kg}$ of NPPNper 1 ton of straw) on the yield of crops and the productivity of the link of acereal-row crop rotation.

\section{Materials and methods}

The research was carried out in 2018-2020 in the scientific and production experiment with a total area of 1.5 hectares of the FSBSI "Kursk FARC", located in Kursk Region, in Medvensky District, Panino settlement, which was laid out in 2017. Equalization sowing is represented by winter wheat. The influence of biopreparations and nitrogen fertilizers using crushed by-products as fertilizers on the productivity of the cereal-row crop link of the crop rotation "oilseedsunflower - spring barley soybean" was studied in four variants of scientific and production experiment. The varieties of the cultivated crops in the experiment are spring barley, variety Suzdalets, oilseed sunflower, variety Imeria, and soybean, variety "Kazachka".

The experiment was laid out in accordance with the generally accepted methods [22] in three-fold replications, the crops were grown according to the recommended technologies under the conditions of CChR.

In all the variants of the experiment, after harvesting the previous crops, all by-products (crushed plant residues) were used as fertilizer by surface embedding them in the soil.

The treatment of the soil and by-products of crops with biopreparations was carried out with an OP-2000/24 sprayer. The application of ammonium nitrate was carried out with a mounted spreader $\mathrm{PH}-0.8$ before embedding the crop and root residues. The crushed plant residues were embedded in the soil with a disc harrow to a depth of 10 to $12 \mathrm{~cm}$. 40 days after that primary moldboard plowing of the soil for grain crops was carried out to a depth of 20 to $22 \mathrm{~cm}$.

The yield of spring barley and soybean was determined when harvesting with a Sampo-500 combine harvester from an area of $600 \mathrm{~m}^{2}(50 \mathrm{~m} \times 12 \mathrm{~m})$, as well as manually from meter-long accounting plots along the diagonal of the plot in three-fold replications The yield of sunflower seeds was taken into account during harvesting by the Don- 1500 combine harvester using a lifter device from an area of $600 \mathrm{~m}^{2}(50 \mathrm{~m} \times 12 \mathrm{~m})$ and manually according to the currently used methods from an area of $10 \mathrm{~m}^{2}$.

The design of the experiment included the following variants:

1. crushed by-products of crop rotation crops (control);

2.crushed by-products of crop rotation crops + nitrogen fertilizers at the rate of $10 \mathrm{~kg}$ NPPNper 1 ton of cereal straw;

3. crushed by-products of crop rotation crops + biopreparations (seed treatment with Gribofit(2 1/t) and Imunazot $(3 \mathrm{l} / \mathrm{t})$ before sowing + soil treatment before sowing with Gribofit (5 1/ha) and Imunazot (3 1/ha) + treatment of crops 2 times during the growing season with Gribofit (5 1/ha) and Imunazot (3 1/ha) + treatment of plant residues with Gribofit (5 1/ha) and Imunazot (3 1/ha) before embedding them;

4. crushed by-products of crop rotation crops + biopreparations (seed treatment with Gribofit(2 1/t) and Imunazot $(3 \mathrm{l} / \mathrm{t})$ before sowing + soil treatment before sowing with Gribofit (5 1/ha) and Imunazot ( 3 l/ha) + treatment of crops 2 times during the growing season with Gribofit (5 1/ha) and Imunazot (3 1/ha) + treatment of plant residues before their embedding with Gribofit ( 5 l/ha) and Imunazot $(3 \mathrm{l} / \mathrm{ha})+$ nitrogen at the rate of $10 \mathrm{~kg}$ of NPPN per 1 ton of cereal straw.

The main active components of biopreparations used in agrobiotechnologies are cultures of two microorganisms: the fungus Trichoderma, presented in the form of a biopreparation Gribofit, and Pseudomonas, presented in the form of Imunazote. Gribofit is an environmentally safe biofungicide, growth stimulator, and phosphate mobilizer. The preparation contains spores and mycelium of the fungus Trichoderma, as well as biologically active substances produced by the fungus during industrial cultivation (antibiotics, enzymes, vitamins, phytohormones). Imunazot is a biological preparation based on the rhizospheric bacteria Pseudomonas, a phosphate mobilizer of contact and systemic action. It has a growth-stimulating activity, increases germination and germination energy, promotes the enhanced development of the root system of plants.

The soil of the experimental field is a typical slightly eroded heavy-loamy chernozem on a carbonate loess-like loam. At the beginning of the experiment, the average humus content in the arable soil layer (according to Tyurin method) was $4.98 \pm 0.15 \%$. The reaction of the soil medium was neutral or close to neutral (pHsalt was 6.3 to 6.5). The content of exchangeable calcium was 22.0 to $23.3 \mathrm{mg}$-eq./100 $\mathrm{g}$ of soil, mobile (according to Chirikov 
method) forms of phosphorus and potassium were 8.8 to $12.0 \mathrm{mg} / \mathrm{kg}$ and 9.7 to $11.2 \mathrm{mg} / \mathrm{kg}$, respectively, total nitrogen (according to Kjeldahl method) was 0.22 to $0.23 \%$, exchangeable ammonium (according to the TSINAO method (GOST 26487-85) was 10.9 to 13.2 $\mathrm{mg} / \mathrm{kg}$, nitrate nitrogen (according to the GrandvalLejeune method) was 4,8 to $5,1 \mathrm{mg} / \mathrm{kg}$ of soil.

Agrometeorological conditions during the study period were characterized by unstable moisture supply and temperature conditions. Thus, in 2018 the air temperature in spring was $8.2-9.0^{\circ} \mathrm{C}$, which is close to the long-term averagevalues, the amount of precipitation was insignificant: $21-40 \mathrm{~mm}$ (26-49\% of the norm). During the summer period, there was a sharp increase in temperature by $5.8^{\circ} \mathrm{C}$, compared with the long-term average values. Precipitation during this period was uneven: in July the amount of precipitation was $228 \%$, and in August $6 \%$ of the climatic norm.

The average monthly temperature in the spring of 2019 was higher than usual by $2-3^{\circ} \mathrm{C}$, and the amount of precipitation was $65 \mathrm{~mm}$, or $83 \%$ of the seasonal norm. In general, during the summer period, the amount of precipitation was $100-150 \mathrm{~mm}$, or $50-65 \%$ of the norm with an elevated air regime. There was soil drought.

The weather conditions of the growing season in 2020 were not the best for the development of plants. In spring April and May were colder than usual. The average monthly temperature in April and May deviated from the norm by $-0.6^{\circ} \mathrm{C},-2.6^{\circ} \mathrm{C}$. The average monthly temperature in March 2020 was by $6.2^{\circ} \mathrm{C}$ higher, and in April, May by $-0.6^{\circ} \mathrm{C},-2.6^{\circ} \mathrm{C}$ lower than normal. The amount of precipitation in March was 53\%, in April 59\%, in May $183 \%$ of the norm. Thus, March was warmer and drier than usual, while April and May were cooler and May was wetter than usual.

The experimental data were processed by methods of mathematical statistics using Microsoft Office EXCEL 2010 software tools.

\section{Results and Discussion.}

Surface embedding of plant residues with biological preparations in the cereal-row crop link of the crop rotation provided an increase in the yield of oilseed sunflower in relation to the control, by $1.22 \mathrm{t} /$ ha at LSD05 $=0.26 \mathrm{t} / \mathrm{ha}$. Nitrogen fertilizers increased the yield of sunflower seeds by $1.62 \mathrm{t} / \mathrm{ha}$.

The use of joint application of biological preparations with nitrogen fertilizers also led to an increase in the yieldof sunflower, where the increase in relation to the control was $1.58 \mathrm{t} / \mathrm{ha}$. But the value of this indicator was at the level of the yield of the variant with the application of nitrogen fertilizers and by $0.36 \mathrm{t} / \mathrm{ha}$ exceeded the yield of sunflower with the use of biopreparations Gribofit and Imunazot (variant 3).

The application of biopreparations with crushed plant residues contributed to an increase in the yield of spring barley, in relation to the control, by $0.42 \mathrm{t} / \mathrm{ha}$ at LSD05 $=$ $0.09 \mathrm{t} / \mathrm{ha}$. There was an increase in the yield of barley grain in the variant with nitrogen fertilizers by $0.52 \mathrm{t} / \mathrm{ha}$. The variant of co-application of biopreparations with nitrogen fertilizers was inferior in terms of barley yield, both to the variant with the use of biopreparations alone (variant 3 ) and to the effect of nitrogen fertilizers (variant 2) by 0.22 and $0.36 \mathrm{t} / \mathrm{ha}$, respectively.

Cold April and May of 2020, lack of precipitation during the formation of soybeans contributed to the low yield of soybeans in the experiment using the biologizationpractice.

Treatment of crushed by-products with biopreparations, and $10 \mathrm{~kg}$ ofNPPN per 1 ton, inoculation of soybean seeds with microbiological preparations (Imunazot + Gribofit) and their treatment of soil and crops (variant 4) had a significant impact on soybean yield and provided an increase in yield of $47.9 \%$ compared to the control. When applying biopreparations without nitrogen mineral fertilizers (variant 3 ), the increase in soybean yield was $22.9 \%$. The largest increase in the soybean yield $(52.1 \%)$ was obtained in the variant with surface embedding of crushed by-products with $10 \mathrm{~kg}$ of NPPN per 1 ton (variant 2). This confirms the important effect of the application of nitrogen fertilizers with barley straw(applied in 2019), with a wide C: $\mathrm{N}$ ratio.

The productivity of cereal-row crop link of the crop rotation in all the fertilized variants was superior to the control. But higher efficiency was noted when nitrogen fertilizers were applied against the background of embedded crushed plant residues, it was 10.67 thousand of grain units per 1 ha, which exceeded the control by 3.19 thous and of grain units per 1 ha $(42.6 \%)$ (Figure 1$)$.

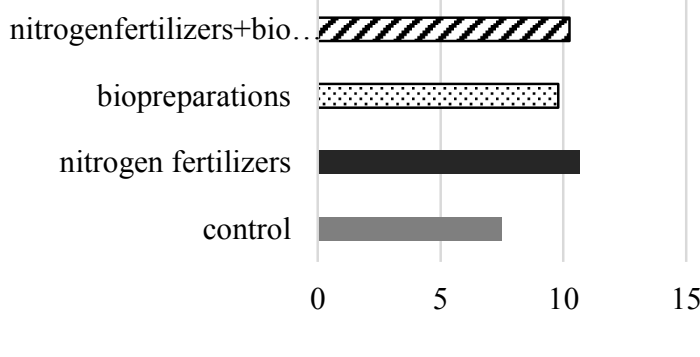

Productivity, thous and grainunits/ha

Fig. 1 Productivity of acereal-row crop link of the crop rotation when biopreparations and nitrogen fertilizers are applied against the background of surface embedded by-products.

The practice of joint application of nitrogen fertilizers with biopreparations against the back ground of surface embedded crushed crop by-products was slightly inferior to the variant with the application of nitrogen fertilizers alone, but provided an increase in productivity compared with the control (variant 1) and the effect of biopreparations (variant 3 ) with surface embedded plant mass by 2,87 thousand and 0,45 thousand grain units per 1 ha, respectively.

Therefore, the application of nitrogen fertilizers with crushed by-products (variant 2) is more effective than the use of biopreparations (Gribofit and Imunazot).

It is possible that low activity of the rhizospheric bacteria of the represented biopreparations is due to the fact that the main growing season of crop formation, soybean in particular, was associated with unfavorable 
climatic conditions. This led to a decline in the biological activity of both soil microorganisms and the activity of microorganisms of microbiological preparations. As a result, there was a slowdown in the process of transformation of plant residues and the release of nutrients necessary for crops, and as a further result, a decrease in the productivity of the cereal-row crop link of the crop rotation when applying biopreparationsagainst the background of surface embedded by-products.

\section{Conclusion}

Thus, the application of nitrogen fertilizers with byproducts provided an increase in the yield of oilseed sunflower, in relation to the control, by $1.62 \mathrm{t} / \mathrm{ha}(51.9 \%)$, spring barley by $0.52 \mathrm{t} / \mathrm{ha}(23.3 \%)$, soybean by $0.25 \mathrm{t} / \mathrm{ha}$ (52.1\%), the use of biopreparations by $1.22 \mathrm{t} / \mathrm{ha}(39.1 \%)$, $0.42 \mathrm{t} / \mathrm{ha}(18.0 \%)$, and $0.11 \mathrm{t} / \mathrm{ha}(22.9 \%)$, respectively.

The use of by-products as organic fertilizers and biopreparations (Gribofit and Imunazot) had a positive impact on crop yields and productivity of the cereal-row crop rotation link.

The work was carried out within the framework of the Statetasks of FSBSI «Federal Agricultural Kursk Research Center» on topic No. 6032-2019-0014

\section{References}

1. A. Kabata, Microelements in soils and plants 4thed. 534 (London-New York: CRC. Press Taylor\&Francis GroupBoca-Raton, 2011)

2. U. Arshad, M. Sarfraz, M. Sadig, S. Khasana, Asian Bull.Plant Sci. 1 (2012)

3. T. Ryabchinskaya, T. Zimina Agrochem. 12 56-61 (2017)

4. Y.Tsvey, O. Prisyazhniuk, O. Gorash, R. Klimysheva, I. Shudrenko Arch. of Plants 20 268-274 (2020)

5. I. Rusakova Juvenis scientia, 9 4-9(2018)

6. V. Petrov, V. Chebotar Agr. Biol. 3 103-108 (2012)

7. A. Rosmana, R. Sacraban, S. Sjam, A. Asman, B.Y.S. Pandin J. Animal and Plant Sci. 29 (1), 291-298 (2019)

8. L. Pusenkova, Y. Ilyasova, O. Lastochkina, I. Vaximov, S. Leonova Euras. Soil Sci. 10 1205-1213 (2016)

9. De Kok-Mercado Omar, Theses and Dissert. 114 (2015).

10. N. Magan, P. Hand, I. Kirkwood, J. Linch Soil Biol. \& Biochem. 21 15-22 (1989).

11. M. Schenckzu Schwtinsderg-Mickan \& T. Müller, J. Plant Nutr.\& Soil Sci. 172(5) 704-712 (2009)

12. S. Tenelli, de Oliveira, R. Bordonal, L. Barbosa, J. Carvalho Bioenergy Res. 12 (4) 764-777 (2019)

13. K. Byung-Chul, N. Kyonghile, C. Yongju Biochem. Engin. J. 140 108-114 (2018)
14. P. Li, D. Zhang, X. Wang, Z. Cui J. Microbiol. Biotechnol. 22 126-132 (2012)

15. Omar de Kok-Mercado, Graduate Theses \& Dissertations (2015)

16. O. Esther, T. Hong, G. Hui Afric. J. Microbiol. Res. 7(28) 3597-3605 (2013)

17. G. Breskina, A. Kuznetsov, N. Chuyan Agrochem. Bull. 5 41-43 (2019)

18. E. Vysotskaya, M.Krekoten, VGA Bull. 1(52) 20-26 (2017)

19. S. Shejbalova, J. Cerny, F. Vasak, V. Kulhanek, Plant, Soil and Environ. 7(60) 290-296 (2014)

20. S. Mundus, A. Carstensen, S. Husted Field Grops Res. 212 1-10 (2017)

21. O. Syrmolot, E. Baideliuk, N. Kocheva Achiev. Sci. \& Technol. in Agribusiness. 8(34) 70-74 (2020)

22. B. Dospekhov, I. Vasiliev, A. Tulikov Laboratory Manual for Agriculture 387 (M., Agropromizdat, 1987) 